\title{
Evaluation of physico-chemical and organoleptic characteristics of sweetened stirred plum (Prunes domestica) yoghurt during storage
}

\author{
Shalini Arora ${ }^{1}$, Gaurav Chaudhary ${ }^{2}$, Upasana Yadav ${ }^{3}$ Tarun Pal Singh $^{4}$ and Shikha Bathla ${ }^{5}$
}

Received: 09 June 2021 / Accepted: 22 June 2021 / Published online: 07 September 2021

(C) Indian Dairy Association (India) 2021

\begin{abstract}
The objective of the present study was to develop sweetened stirred fruit yoghurt incorporated with plum fruit pulp. The pulp was added @ 10,15 and 20\% and the formulated sweetened fruit yoghurt was studied for various physicochemical ( $\mathrm{pH}$, acidity, syneresis, and tyrosine value) and organoleptic characteristics during storage. Plain (natural) and plum yoghurt were observed significantly different and the results showed a significant $(\mathrm{p}<0.05)$ decrease in $\mathrm{pH}$ and increased acidity, syneresis, and tyrosine value among various treatments and during storage. The addition of plum fruit in natural yoghurt modified the sensorial characteristics of the formulated product. Fruit yoghurt prepared by the addition of plum at $10 \%$ level was most acceptable with significantly improved sensory characteristics and shelf life of 12 days during refrigerated storage.
\end{abstract}

Keywords: Acidity, Organoleptic quality, Plum, Syneresis, Tyrosine value, Yoghurt

${ }^{1}$ Department of Dairy Technology, CoDST, Lala Lajpat Rai University of Veterinary and Animal Sciences, (Hisar)-125004, Haryana, India

${ }^{2}$ Department of Horticulture, CCR (PG) College, Muzaffarnagar, Chaudhary Charan Singh University Meerut, Uttar Pradesh- 250001, India

${ }^{3}$ Department of Nutrition and Dietetics, Manav Rachna International Institute of Research and Studies, Faridabad 121004, Haryana, India

${ }^{4}$ Goat Products Technology Laboratory, ICAR-Central Institute for Research on Goats, Makhdoom, Farah-281122, Uttar Pradesh, India

${ }^{5}$ Krishi Vigyan Kendra, Punjab Agricultural University, Ludhiana 144516, Punjab, India

Shalini Arora $(\bowtie)$

Department of Dairy Technology

College of Dairy Science and Technology

Lala Lajpat Rai University of Veterinary and Animal Sciences

Hisar 125004, Haryana, India

E-mail id: shaliniarora.luvas@gmail.com; Mobile: 7988425439

\section{Introduction}

Consumers cherish consumption of milk and milk product (Arora et al. 2021) and yoghurt is a widely consumed fermented dairy product because of its potential health benefits (Bernat et al. 2015). It is prepared by lactose fermentation in milk by action of starter organisms such as L. delbrueckii subsp. bulgaricus and S. thermophiles (Fiorda et al. 2016). Yoghurt is readily digestible (even to people with lactose intolerance) than milk, as the various milk constituents viz., protein, fat, and lactose, undergo partial hydrolysis during fermentation (Papastoyiannidis et al. 2006). Besides the nutritional content and health benefits of yoghurt due to living microorganisms (EFSA 2010), its physico-chemical properties, perceptiveness, and textural characteristics are vital for its marketability.

Different varieties of yoghurt are being marketed globally, including plain, set, stirred, Greek, drinkable, fruit, organic, creamy, and luxury yoghurts (Cassell 2014). Furthermore, to increase the nutritional characteristics and to upgrade it technologically, various food ingredients are being used for milk supplementation, including milk protein (Peng et al. 2009), whey protein (Sharanagouda, Shankarlingayya, \& Arora 2019), dried dairy ingredients (Isleten \& Karagul-Yuceer 2006), minerals and fibres (Vasiljevic et al. 2007).

The incorporation of fruits and additives during yoghurt production has further enhanced its color, taste, nutritional features, functionality, and therapeutic properties as the customer tends to reject the synthetic additives in food (Cakmakcý et al. 2012). Fruits contain natural pectin and sugars when mixed with the yoghurt, raises its viscosity and consistency and thereby improves the organoleptic characteristics (Nongonierma 2007). Further, fruits contain high amounts of phytochemicals, including polyphenols, carotenoids, flavonoids, vitamins, and minerals that reduce oxidative stress and, hence, lowers the risk of degenerative diseases and stops macromolecular oxidation (Adelia et al. 2011). Various fruits like papaya, apricots, pear, blueberries, peaches, cherries are frequently used during yoghurt production (Arslan S \& Ozel 2012). The fruits can be incorporated either as single fruit or blends of various fruits. 
Non-traditional fruits like lemon, melon, orange, plum, and prunes are the fruit and fruit flavors used in yoghurt (Routray and Mishra, 2011). Plums (Prunes domestica) are rich sources of vitamins (including vitamins $\mathrm{C}, \mathrm{B} 1, \mathrm{~B} 2$, and A), minerals (with the highest bioavailability of iron) (Stacewicz-Sapuntzakis 2013), antioxidants, polyphenolics, and dietary fiber. Besides, the prebiotic effect of dried plum was found in rats fed on a plum rich fermented diet (Seong-Eun et al. 2014). Further, frozen yoghurt prepared from goat milk and enriched with jambolan (Black plum) showed desirable bioactive and technological attributes (Bezerra et al. 2015). Therefore, to provide natural flavour, colour, and other nutritional, pharmacological and techno-functional benefits, it would be advantageous to incorporate fruit like plum in milk products such as sweetened yoghurt. Hence, in the present study, the effect of plum fruit pulp (10,15, and 20) addition on the physico-chemical and organoleptic characteristics of the formulated yoghurt, was examined immediately after production and storage.

\section{Materials and Methods}

Freshly pooled buffalo milk was procured from the experimental dairy plant, Department of Livestock Product Technology, LUVAS, Hisar. Freeze-dried starter cultures of lactobacillus bulgaricus and Streptococcus thermiphillus were procured from NCDC, NDRI, Karnal. Spray-dried skim milk powder (SMP) of Nova brand manufactured by Sterling Agro Industry Ltd., Sonepat (Haryana), was procured from the local market. The milk was standardized to the desired fat and solid not fat (SNF) level. SNF content of the milk was raised by the addition of calculated quantity of low heat spray-dried skim milk powder. Pectin (high methoxy) was obtained from Central Drug House, New Delhi. Food-grade sugar was obtained from the local market.

Plum (Prunes domestica) of good quality, free from any external defect, damage or spoilage, were procured from local fruit and vegetable market, Hisar.

Polypropylene container with polyethylene leak-proof screw-seal caps, (100 mL standard cups, Model No: 510010.0, M/s Tarsons Products Pvt. Ltd., Kolkata) were used to pack and store fruit yoghurt.

\section{Preparation of fruit pulp}

Good qualities plum fruit was used for making fruit pulp. The fruit's skin was peeled off, and the stone and entire damaged portion were removed. The pulp was blended in the blender to make it homogeneous. The fresh fruit pulp was blanched (by indirect heating at $90^{\circ} \mathrm{C}$ for $15 \mathrm{~s}$ ), cooled, and stored at $-18^{\circ} \mathrm{C}$ in glass jars until use.

\section{Preparation of stirred yoghurt}

Fresh buffalo milk was standardized to desired fat $(3.0 \%)$ and SNF (8.5\%) level. Sugar@6\%, SMP@7\% and stabilizer (pectin) (a) $0.2 \%$ was added in the milk to raise the TS content $(24 \%)$ of yoghurt milk mix (YMM). The YMM was first was preheated to $65^{\circ} \mathrm{C}$ and homogenized (Two-stage, $2000 \mathrm{psi}$, and $500 \mathrm{psi}$ ). After homogenization, the YMM was heated to $90^{\circ} \mathrm{C}$ for $15 \mathrm{~min}$ followed by immediate cooling $42^{\circ} \mathrm{C}$ and inoculation with a culture combination comprising of Lactobacillus bulgaricus and Streptococcus thermiphillus@2g/100 g level (in the ratio 1:1) at $42^{\circ} \mathrm{C}$ for 5-6 h to obtain firm curd. Plain yoghurt obtained was cooled in the refrigerator at $5 \pm 1{ }^{\circ} \mathrm{C}$ for $2 \mathrm{~h}$ and then blended with fruit pulps (plum)@10\%,15\%, and 20\%. The fruit yoghurt was filled in pre sanitized plastic container $(100 \mathrm{ml})$ and refrigerated until subjected to various analysis.

\section{Chemical analysis of raw material}

\section{Chemical analysis of milk}

Total solids in yoghurt milk mix (YMM) were estimated as per IS: 1479-part-II (1961) method. Fat content in milk was estimated as per IS: 1224 (1958) method. pH of the milk sample was recorded using $\mathrm{pH}$ meter (Systronics). Acidity of milk sample was estimated as per A.O.A.C. (1990) method.

\section{Chemical analysis of fruit}

Fruit sample were analyzed for total soluble solids (TSS), acidity, ascorbic acid, and total phenols. TSS of the fruit was tested using Hand Refractometer (range of $0-32 \%$ ). The acidity of the fruit sample was calculated as citric acid in meq./L (Ranganna 2002). The ascorbic acid was determined by the method of A.O.A.C. (1990). The $\mathrm{pH}$ of the fruit sample was analyzed using $\mathrm{pH}$ meter (Systronics). Total phenols in fruit were determined by the method of Amorium (1977).

\section{Chemical analysis of fruit yoghurt}

The $\mathrm{pH}$ of the fruits yoghurt was analyzed using $\mathrm{pH}$ meter (Systronics). Acidity of yoghurt samples was estimated by A.O.A.C. (1990). The method described by Rodarte et al. (1993) was followed for the estimation of syneresis. Tyrosine value was determined as per the method of Strange et al. (1977).

\section{Sensory evaluation}

Sensory evaluation of the plain (control) and stirred fruit yoghurt samples was performed using 9-point hedonic scale. The samples were drawn periodically (at 4 days intervals) from the refrigerator before served to the panelists. Ten trained judges from CoFST, HAU, Hisar, having adequate knowledge about the sensory evaluation methodology and product characteristics, were the sensory evaluation panelist. The sensory attributes assessed 
were colour and appearance, flavour, taste, body and texture, and overall acceptability.

\section{Statistical Method}

The data obtained in the present investigation was subjected to analysis of variance (ANOVA) design using OP Stat, Statistical analysis software developed by the Department of Mathematics and Statistics, CCS, HAU Hisar. The critical difference (CD) at $5 \%$ level of significance was used for making a comparison among different treatments $(\mathrm{N}=3$ and control) and during 16 days storage (at 4 days intervals).

\section{Result and discussion}

\section{Chemical composition of the raw material}

The chemical compositions of the yoghurt milk mix (YMM) and plum fruit are presented in Table 1. Standardized milk contained $3.10 \%$ fat, and $8.59 \%$ SNF. Acidity and $\mathrm{pH}$ values of milk sample were within the normal range. Yoghurt milk mix (YMM) contained $2.70 \%$ fat and $24.10 \%$ total solid. The chemical analysis of fruit pulp revealed the high acidity $(110 \mathrm{meq} / \mathrm{L})$ and total phenols (234mg/100g) in the plum pulp.

\section{Physicochemical analysis of yoghurt during storage}

\section{Acidity and $\mathrm{pH}$}

Changes in acidity of plain and fruit yoghurt during storage are presented in Fig. 1A. Maximum acidity was observed in plum yoghurt with $20 \%$ added fruit pulp. A significant increase $(\mathrm{p}<0.05)$ in acidity was observed for all fruit yoghurt samples compared to control during storage. This can be attributed to the higher acidity of fruits contributing to increased acidity in fruit blended yoghurt. According to Dyanchenko(1971), lactic acid is essential during yoghurt manufacture to assist in destabilizing the casein micelles. The micelles become gradually depleted of calcium, leading to coagulation of casein at $\mathrm{pH} 4.6$ to 4.7 , hence the formations of yoghurt gel. Acid development is an essential requirement for a characteristic flavour in yoghurt. However, increased acidification is considered the most common reason for the inferior keeping quality of fermented milk (Melling 1979).

Fig 1.B represents changes in $\mathrm{pH}$ of different variants of stirred fruit yoghurt. $\mathrm{pH}$ regulates various chemical and microbiological reactions and is vital concerning public safety (Jayasinghe et al. $2015)$. There were statistically significant $(\mathrm{p}<0.05)$ variations in $\mathrm{pH}$ during storage, but no significant difference was observed by adding different levels of fruit pulp into the formulated yoghurts. Initially, the $\mathrm{pH}$ of all yoghurt variants ranged from 4.51-4.56, which decreased to $4.05-4.12$ on the $16^{\text {th }}$ day of storage that possibly due to the growth and metabolic activities of acidforming bacteria (Jayasinghe et al. 2015; Lucey 1998). Further, when the sources of sugar get depleted, the microorganisms begin to utilize proteins, and the breakdown products lower the $\mathrm{pH}$ (Jayalalitha et al. 2015). The results for $\mathrm{pH}$ in the present study were similar to fruit yoghurt containing dragon fruit reported by Jayasinghe et al. (2015) and the work on soy milk and mango pulp enriched formulated yoghurt(Jayalalitha et al. 2015).

\section{Syneresis (wheying off)}

Syneresis is evaluated as whey separation from cultured dairy products without external force (Peng et al. 2009). Stirred gel products with high viscosity resist wheying off or syneresis during storage. Further, higher whey separation in the yoghurt is associated with gel instability related to the $\mathrm{pH}$ (Lucey 1998).

Changes in \% syneresis of different samples of yoghurt during storage is presented in Fig. 2. The variation in \% syneresis was statistically significant $(\mathrm{p}<0.05)$ during storage and among other treatments. The initial \% syneresis of plain yoghurt was 23.4, which then increased up to $27.3 \%$ at $16^{\text {th }}$ day of storage. The syneresis of plum yoghurts at zero day ranged from $26.8-27.2 \%$. A significant $(\mathrm{p}<0.05)$ increase in $\%$ syneresis was observed with the addition of fruit pulp in plain yoghurt during storage.

Table 1 Composition of raw materials used for the preparation of stirred plum yoghurt

\begin{tabular}{lllc}
\hline Parameters & \multicolumn{2}{c}{ Milk } & \multicolumn{1}{c}{ Plum } \\
\cline { 2 - 4 } & Standardized Milk & Yoghurt Milk mix* & $110 \pm 5.90$ \\
\hline Acidity** & $0.16 \pm 0.12$ & $0.16 \pm 0.02$ & $3.41 \pm 0.24$ \\
pH & $6.70 \pm 0.02$ & $6.72 \pm 0.02$ & - \\
Fat $(\%)$ & $3.10 \pm 0.05$ & $2.70 \pm 0.05$ & - \\
SNF $(\%)$ & $8.59 \pm 0.14$ & - & $11.4 \pm 0.28$ \\
T.S.S (\%) & - & - & - \\
T.S $(\%)$ & $11.6 \pm 0.19$ & $24.10 \pm 0.50$ & $234 \pm 0.34$ \\
Total phenols (mg/100g) & - & - & $7.87 \pm 0.37$ \\
Ascorbic acid (mg/100g) & - & - & \\
\hline
\end{tabular}

*Yoghurt Milk mix added with 6\% SMP and 7\% Sugar

** Acidity of the milk was calculated as \% lactic acid and fruit as \% citric acid in meq/L

Values are mean \pm S.E. for $n=3$ 

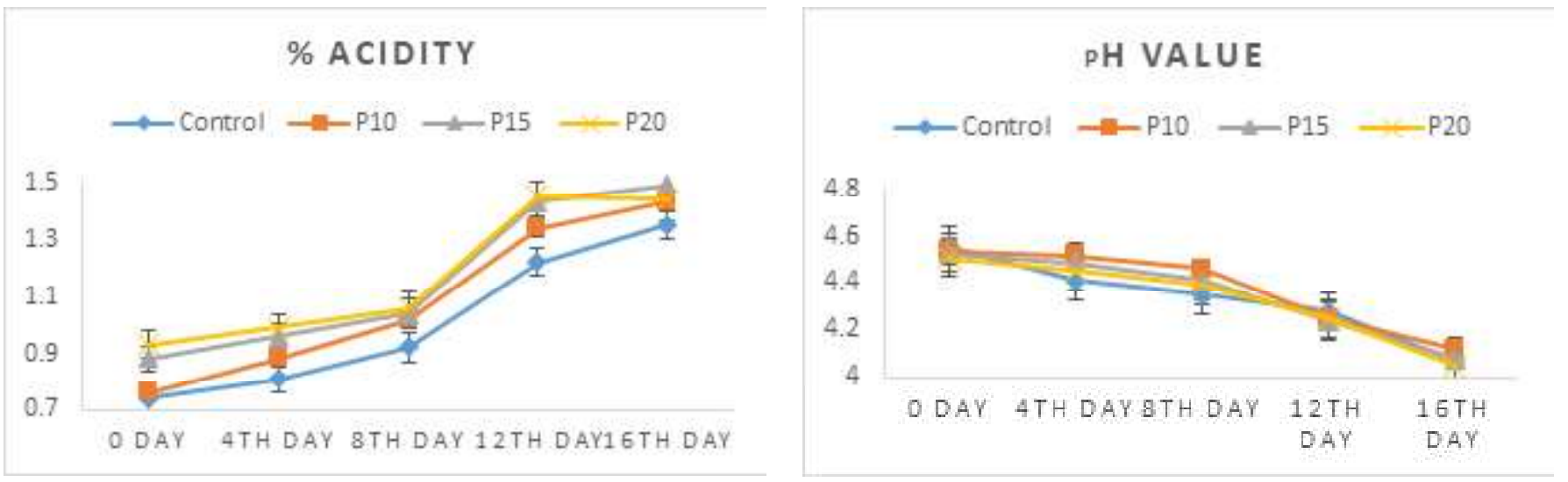

Fig. 1. Effect of different treatments* and storage on 1. (A) acidity (\%) and 1. (B) pH of stirred plum yoghurt

*Treatments -P10, 15, 20= Plum pulp @ 10\%,15\%,20\% level

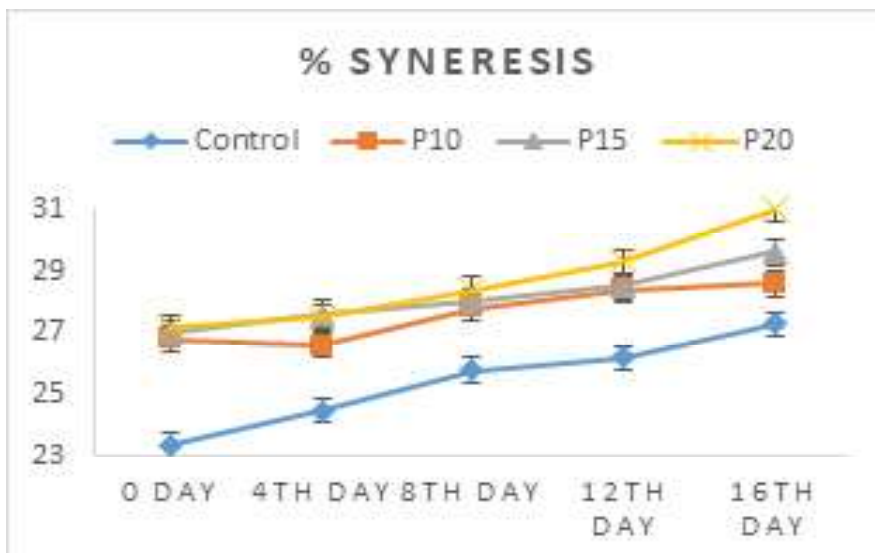

Fig. 2. Effect of different treatments* and storage on syneresis $(\%)$ of stirred plum yoghurt

*Treatments -P10,15,20= Plum pulp@10\%,15\%,20\% level

Maximum syneresis was found in plum yoghurt at $20 \%$ pulp concentration. In the present study, the fruit yoghurt showed a higher wheying off at all stages of the storage period than plain yoghurt. It may be due to the softer body characteristic of yoghurt prepared with added fruit pulp as compared to plain yoghurt. Fruit solids weaken the gel strength by taking space in between the casein micelles. This apart from reducing the gel strength, also reduces the viscosity (El-Etriby et al. 1997). The present results are in agreement with Farooq and Haque (1992). An increase in \% syneresis was also observed in cashew apple stirred yoghurt during 15 days of refrigerated storage (Hafeez 2002). Tarakci and Kukukoner(2004) reported increased syneresis in the samples during entire storage period, but significant after $6^{\text {th }}$ day of storage.

\section{Tyrosine value}

With high protein content and high microbiological activity, fermented milk products are prone to proteolysis. The release of tricarboxylic acid (TCA) insoluble tyrosine indicates proteolysis

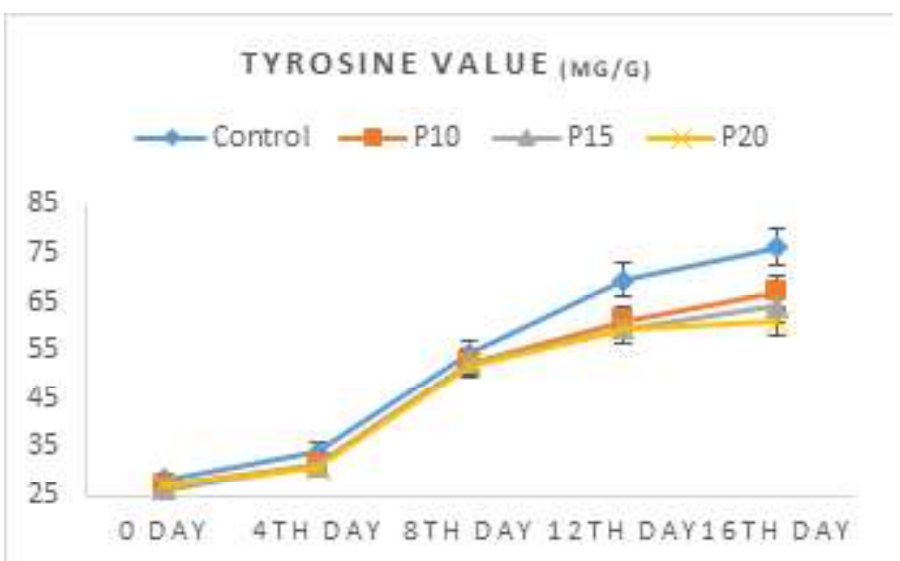

Fig.3 Effect of different treatments* and storage on Tyrosine value $(\mathrm{mg} / \mathrm{g})$ of stirred plum yoghurt

*Treatments -P10,15,20=Plum pulp@10\%,15\%,20\% level

and peptonization of milk. The data regarding the incorporation of plum fruit on tyrosine value of yoghurt during storage has been shown in Fig. 3. The tyrosine value of fruit yoghurt increased significantly $(\mathrm{p}<0.05)$ among various treatments and during storage. However, throughout the storage period, the value was lower in fruit yoghurt compared to plain yoghurt. At $16^{\text {th }}$ day of storage, the tyrosine values of fruit yoghurt ranged from 61.0 to $67.0 \mathrm{mg} / \mathrm{g}$. The slow rate of proteolysis observed in fruit yoghurt compared to plain yoghurt might be due to decreased enzymatic activities of microorganisms in fruit yoghurt, leading to lower tyrosine values (Chawla 1985).

\section{Organoleptic analysis of yoghurt}

The color and appearance, flavour, body, texture, and taste of plain and plum yoghurt samples were evaluated. The sensory profiles were conducted on the coded samples at $0,4^{\text {th }}, 8^{\text {th }}, 12^{\text {th }}$ and $16^{\text {th }}$ day of storage. The result of the sensory quality of the product with different types and levels is presented in Table 2. 
Table 2 Effect of different treatments* and storage $\left(4-7^{\circ} \mathrm{C}\right)$ on the sensory characteristics of stirred plum yoghurt

\begin{tabular}{|c|c|c|c|c|c|c|}
\hline \multirow[t]{2}{*}{ Attributes } & \multirow[t]{2}{*}{ Sample } & \multicolumn{5}{|c|}{ Storage period(days) } \\
\hline & & 0 day & $4^{\text {th }}$ day & $8^{\text {th }}$ day & $12^{\text {th }}$ day & $16^{\text {th }}$ day \\
\hline \multirow{3}{*}{$\begin{array}{l}\text { Color and } \\
\text { appearance }\end{array}$} & Control & $7.53^{\mathrm{cB}+0.47}$ & $7.40^{\mathrm{cB}} \pm 0.3$ & $7.23^{\mathrm{c}} \pm 0.33$ & $6.83^{\mathrm{bB}+0.62}$ & $5.73^{\mathrm{aC}}+0.24$ \\
\hline & $\mathrm{P}_{10}$ & $7.63^{\mathrm{dB}} \pm 0.24$ & $7.45^{\mathrm{cdB}} \pm 0.32$ & $7.17^{\mathrm{C}} \pm 0.41$ & $6.76^{\mathrm{bB} \pm 0.24}$ & $6.07^{\mathrm{aD}} \pm 0.24$ \\
\hline & $\mathrm{P}_{20}$ & $7.17^{\mathrm{dA} \pm 0.20}$ & $6.95^{\mathrm{dA}} \pm 0.47$ & $6.49^{\mathrm{cA}}+0.41$ & $6.03^{\mathrm{bA} \pm 0.24}$ & $5.03^{\mathrm{aA}} \pm 0.23$ \\
\hline \multirow[t]{2}{*}{ Flavour } & Control & $7.67^{\mathrm{cB}} \pm 0.23$ & $7.70^{\mathrm{cC}} \pm 0.41$ & $7.73^{\mathrm{c} \pm} \pm 0.23$ & $6.27^{\mathrm{bB}} \pm 0.45$ & $6.0^{\mathrm{aB} \pm 0.47}$ \\
\hline & $\mathrm{P}_{20}$ & $7.17^{\mathrm{cA}} \pm 0.25$ & $7.22^{\mathrm{cA} \pm 0.4}$ & $7.23^{\mathrm{cA}} \pm 0.21$ & $6.09^{\mathrm{bAB}} \pm 0.42$ & $5.33^{\mathrm{aA}} \pm 0.24$ \\
\hline \multirow[t]{4}{*}{ Body and texture } & Control & $7.83^{\mathrm{dC}} \pm 0.24$ & $7.57^{\mathrm{cdC}} \pm 0.41$ & $7.45^{\mathrm{C}} \pm 0.24$ & $6.25^{\mathrm{bB}} \pm 0.22$ & $5.73^{\mathrm{aC}}+0.41$ \\
\hline & $\mathrm{P}_{10}$ & $7.83^{\mathrm{cC}} \pm 0.23$ & $7.53^{\mathrm{bC}} \pm 0.25$ & $7.35^{\mathrm{bBC}} \pm 0.41$ & $6.27^{\mathrm{bB}} \pm 0.46$ & $5.63^{\mathrm{aC}} \pm 0.41$ \\
\hline & $\mathrm{P}_{15}$ & $7.57^{\mathrm{dB} \pm 0.36}$ & $7.17^{\mathrm{cB}} \pm 0.24$ & $7.17^{\mathrm{cB}} \pm 0.23$ & $6.07^{\mathrm{bA}} \pm 0.62$ & $5.42^{\mathrm{aB}} \pm 0.47$ \\
\hline & $\mathrm{P}_{20}$ & $7.33^{\mathrm{eA}} \pm 0.46$ & $6.89^{\mathrm{dA}} \pm 0.37$ & $6.33^{\mathrm{cA}} \pm 0.21$ & $6.00^{\mathrm{bA}} \pm 0.3$ & $5.17^{\mathrm{aA}} \pm 0.24$ \\
\hline & $\mathrm{P}_{20}$ & $7.02^{\mathrm{cA}} \pm 0.36$ & $6.87^{\mathrm{cbA}} \pm 0.33$ & $6.89^{\mathrm{cA}} \pm 0.52$ & $5.83^{\mathrm{bA}} \pm 0.62$ & $5.37^{\mathrm{aA}} \pm 0.42$ \\
\hline \multirow[t]{4}{*}{ Overall acceptability } & Control & $7.60^{\mathrm{cB}} \pm 0.24$ & $7.27^{\mathrm{bB}} \pm 0.12$ & $7.05^{\mathrm{bB}} \pm 0.42$ & $6.31^{\mathrm{aB}} \pm 0.24$ & $5.84^{\mathrm{aC}} \pm 0.23$ \\
\hline & $\mathrm{P}_{10}$ & $7.81^{\mathrm{cC}} \pm 0.24$ & $7.55^{\mathrm{bC}} \pm 0.22$ & $7.34^{\mathrm{bC}} \pm 0.12$ & $6.52^{\mathrm{aC}} \pm 0.43$ & $6.13^{\mathrm{aD}} \pm 0.62$ \\
\hline & $\mathrm{P}_{15}$ & $7.33^{\mathrm{dA}} \pm 0.2$ & $7.13^{\mathrm{cdB}}+0.32$ & $7.01^{\mathrm{cB}} \pm 0.55$ & $6.23^{\mathrm{bB}} \pm 0.21$ & $5.53^{\mathrm{aB}} \pm 0.12$ \\
\hline & $\mathrm{P}_{20}$ & $7.17^{\mathrm{cA}} \pm 0.42$ & $6.86^{\mathrm{cA}} \pm 0.12$ & $6.60^{\mathrm{bA}} \pm 0.22$ & $6.07^{\mathrm{bA}} \pm 0.21$ & $5.33^{\mathrm{aA}} \pm 0.23$ \\
\hline
\end{tabular}

*Treatments -P10, 15, $20=$ Plum pulp @ 10\%,15\%,20\% level

*On a 9-point hedonic rating scale: 9-like extremely; 1-dislike extremely

abc; $\mathrm{ABC}$ Means \pm S.E. $(\mathrm{n}=10)$ with same superscripts in a column $(\mathrm{A}, \mathrm{B}, \mathrm{C})$ or in a row $(\mathrm{a}, \mathrm{b}, \mathrm{c})$ do not differ signiûcantly $(\mathrm{P} \leq 0.05)$

\section{Color and appearance score $(C \& A)$}

Color parameters are the significant attributes for marketing. Food without visual attraction cannot fetch market access. Thus, the color of formulated foods should remain unaffected after processing and during storage. The color and appearance scores of yoghurts as affected by pulp concentrations is presented in the Table 2. The C\&A scores of various fruit yoghurt differed significantly $(\mathrm{p}<0.05)$. Plum yoghurts at $10 \%$ fruit pulp concentration scored maximum while at $20 \%$ pulp concentration scored minimum. The high concentration of pulp particles decreased the color perception of yoghurt. Further, the decrease in the C\&A scores during storage may be attributed to the increase wheying off(Tarakci and Kukukoner 2004).

\section{Flavour}

The flavour scores decreased significantly $(\mathrm{p}<0.05)$ during storage, and plum yoghurt at $10 \%$ fruit pulp concentration scored maximum, while plum yoghurt at $20 \%$ pulp concentration scored minimum. There was slight improvement in the flavour scores up to $8^{\text {th }}$ day of storage, and then the scores decreased significantly $(\mathrm{p}<0.05)$. During the first week, the increased flavor score might be attributed to biochemical changes and the blending of fruit solids with the yoghurt. The decrease in the flavour scores at the later stages of the storage period might be due to the increased acidity (Table 2). Laye et al. (1993) reported a decrease in flavour scores during storage might be due to decreased $\mathrm{pH}$, accompanied by an increase in alcoholic aroma and the acidic taste of yoghurt. In a study by Tarakci and Kukukoner(2004), an average decrease in the flavour scores (4.01 to 3.73) on 5-point Hedonic scale was observed during storage.

\section{Body and texture $(B \& T)$}

The body and texture scores of yoghurts as affected by fruit types and pulp concentrations have been presented in Table 2. Plum yoghurt at $20 \%$ fruit pulp concentration scored minimum. Tarakci and Kukukoner (2004) observed an average decrease in the B\&T scores during storage from 4.21 to 3.99 on 5-point Hedonic scale. The decrease in average B\&T scores of yoghurts might be attributed to reduction in viscosity and consistency of yoghurts by the addition of fruit pulp. On the contrary, Keating and White (1990) found that prolonged storage led to an increased body and texture scores.

\section{Taste (sensory acidity)}

The average taste score of plain yoghurt was 7.55 , which decreased significantly $(\mathrm{p}<0.05)$ with storage to 6.00 on the $16^{\text {th }}$ day. Plum yoghurt at $10 \%$ fruit pulp concentration scored maximum (7.67), while at $20 \%$ pulp concentration scored minimum (7.02). During storage, the taste score didn't differ significantly up to the mid-storage period due to the blending of fruit pulp in the 
yoghurt. The decrease in scores at later stages might be due to wheying off from the samples or higher sensory acidity.

\section{Overall acceptability $(\mathrm{OA})$}

The average OA score of plain yoghurt was 7.60 , which decreased significantly $(\mathrm{p}<0.05)$ with a storage period to 5.84 on the $16^{\text {th }}$ day. The average OA scores of different fruits yoghurt at zeroday ranged 7.17-7.81. There was a significant decrease in OA with increasing pulp concentrations (from $10 \%$ to $20 \%$ ). The formulated stirred yoghurt received a good acceptability score (like moderately to liked very much) up to $8^{\text {th }}$ day of storage. At the later periods, the scores decreased progressively with an increase in the storage period. However, the fruit yoghurt remained acceptable up to $12^{\text {th }}$ day of storage.

\section{Conclusions}

As demonstrated by the presented research, the overall quality of stirred fruit yoghurts was affected by adding fruit pulp at different concentrations. Fruit yoghurt prepared with added plum was most acceptable at the lowest concentration (10\%). The physico-chemical and sensory evaluation clearly showed that the plain and fruit yoghurt could be stored up to 12 days at $5^{\circ} \mathrm{C}$. This study demonstrated that the most acceptable stirred fruit yoghurt could be produced from plum fruit pulp at $10 \%$ level. The scope of the addition of different stabilizers like gelatin and carrageenan on the overall quality of yoghurt could further be explored.

\section{Acknowledgments}

The author is thankful to the Director, CFST, HAU, Hisar for providing financial assistance to carry out this research work.

\section{References}

A.O.A.C. (1990) Official Methods of Analysis. 15 (ed)., Association of Official Agricultural Chemists. Inc. Washington, D.C

Adelia FF, Marcella CM, Adriana ZM (2011) Identification of bioactive compounds from Syzygium cumini and antioxidant capacity evaluation in different $\mathrm{pH}$ conditions. Food Chem 126: 1571-1578

Amorium HV, Dugall DK, Sharp WR (1977) The effect of carbohydrate and nitrogen concentrations on phenol synthesis in Paul's scarlet rose cells grown in tissue culture. Physiologia Plantarum 39:91-95

Arora S, Gurditta, H, Patel AA, Yadav U, Singh RRB, Rekha (2021). Modelling and optimization of process parameters for production of desiccated Chhana-murki (Indian cottage cheese-based dessert). J Food Sci Technol. Online : https://doi.org/10.1007/ s13197-020-04920-6

Arslan S, Ozel S (2012) Some properties of stirred yoghurt made with processed grape seed powder, carrot juice or a mixture of grape seed powder and carrot juice. Milchwissenschaft 67 281-285
Bernat N, Cha'fer M, Chiralt A, Gonza'lez-Martý'nez C (2015) Development of a non-dairy probiotic fermented product based on almond milk and inulin. Food Sci Technol Int 21: 440-453

Bezerra M, Araujo A, Santos K, Correia R (2015) Caprine frozen yoghurt 488 produced with fresh and spray dried jambolan fruit pulp (Eugenia jambolana Lam) and Bifidobacterium animalis subsp. lactis BI-07. LWT - Food Sci Technol 62: 1099-1104

Cakmakcý S, Cetin B, Turgut T, Gurses M, Erdoðan A (2012) Probiotic properties, sensory qualities, and storage stability of probiotic banana yoghurts. Turkish J Vet Animal Sci 36: 231-237

Cassell D (2014) Flavour trends: Yoghurt's fruitful union. Retrieved from https://www. Food processing.com/articles/2014/flavour-trendsyoghurt/.

Chawla AK (1985) Certain technological parameter for commercial production of yoghurt. PhD. Thesis Kurukshetra University. Kurukshetra.

Dyanchenko PF (1971) Value added cultures. Dairy Sci Abstracts : 33-56

EFSA (2010) Panel on Dietetic Products, Nutrition and Allergies (NDA) Scientific Opinion on the substantiation of health claims related to Yoghurt cultures and improving lactose digestion (ID 1143, 2976) pursuant to Article 13(1) of Regulation (EC) No1924/2006. EFSA,8(10) 1763.doi:10.2903/j.efsa.2010.1763. Available online: www.efsa.europa.eu/efsajournal.htm.

El-Etriby HM, El-Dairouty RK, Zoghloul AH (1997) Physico-chemical and bacteriological ultra-filtered milk retentate using Glucono-Deltalactone (GDL). Egyptian J Dairy Sci 25: 349.

Farooq H, Haque ZU (1992) Effect of sugar esters on textural properties of non-fat low calorie yoghurt. J Dairy Sci 75: 2670-2680

Fiorda FA, De Melo Pereira GV, Thomaz-Soccol V, Rakshit SK, Soccol CR (2016) Evaluation of a potentially probiotic non-dairy beverage developed with honey and kefir grains: Fermentation kinetics and storage study. Food Sci and Technol Int 22: 732-742

Hafeez K (2002) Preparation and evaluation of apple based stirred yoghurt. Faisalabad Pakistan UAF 861

IS: 1224 (1958) Indian Standards. Determination of milk fat by Gerber method. Indian Standard Institution, New Delhi

IS: 1479-Part-II (1961) Indian Standards. Chemical analysis of milk, Indian Standard Institution, New Delhi

Isleten M, Karagul-Yuceer Y (2006) Effects of dried dairy ingredients on physical and sensory properties of nonfat yoghurt. J Dairy Sci 89: 2865-2872

Jayalalitha V, Manoharan A, Balasundaram B, Elango A (2015) Formulation of value enriched yoghurt with soy milk and mango pulp. Journal Nut Food Sci 5: 1-4

Jayasinghe O, Sumali F, Jayamanne V, Hettiarachchi D (2015) Production of a novel fruit-yoghurt using dragon fruit (Hylocereus undatus 1.). European Scientific J: 11

Keating KR, White CH (1990) Effect of alternative sweeteners in the plain and fruit flavoured yoghurts. J Dairy Sci 73: 54-72

Laye I, Karleskind D, Morr CV (1993) Chemical, microbiological and sensory properities of plain nonfat yoghurt. Food Sci 58: 991-1000

Lucey JP, Munro PA, Singh H (1998) Whey separation in acid skim milk gels made with glucono-ä-lacton: effects of heat treatment and gelation temperature. J Texture Stud 29: 413-426

Melling H (1979) Occurrence, characterization and origin of excess acidity in cultured milk products. Milchwissenschaft 34:1844

Nongonierma AB, Cayota P, Springettb M, Quere JL, Cachond R, Voilley A (2007) Transfers of small analytes in a multiphasic stirred fruit yoghurt model. Food Hydrocolloids 21: 287-296

Papastoyiannidis G, Polychroniadou A, Michaelidou AM, Alichanidis E (2006) Fermented milks fortified with B-group vitamins: Vitamin 
stability and effect on resulting products. Food Sci Technol Int 12:521-529

Peng Y, Serra M, Horne DS, Lucey JA (2009) Effect of fortification with various types of milk protein on the rheological properties and permeability of non-fat set yoghurt. J Food Sci 74: 666-673

Ranganna S (2002) Manual of analysis of fruit and vegetable products. Tata McGraw Hill Publishing Co. Ltd., New Delhi

Rodarte C W, Galven MV, Farres A, Gallardo F, Marshall VE, Garibay M G (1993) Yoghurt production from reconstituted skim milk powders using different polymer forming starter cultures. J Dairy Res 60:247254

Routray W and Mishra HN (2011) Scientific and technical aspects of yogurt aroma and taste: A review. Comp Rev Food Sci Food Safety 10:208-220. https://doi.org/10.1111/j.1541-4337.2011.00151.x

Seong-Eun K, Sun Moon K, Allen Y, Zachary M, Walte M, Gene K; Stacy W, Konstantinos T, Mark P, Christopher C 2014 The Effect of dried plum on targeted gut flora and host gene expression in a rat model of post-infectious IBS, American J Gastroenterol 109: S537 S537

Sharanagouda B, Shankarlingayya VS, Arora S (2019) Optimization of inoculation level of probiotics ( $L$. acidophilus LA5; B. bifidum $B B 12$ ) on the quality parameters of whey protein enriched probiotic concentrated yoghurt. Haryana Veterinarian 58: 220-223

Stacewicz-Sapuntzakis M (2013) Dried plums and their products: composition and health effects-an updated Review. Critical Rev Food Sci Nut 53:1277-1302. DOI: 10.1080/10408398.2011.563880 Strange ED, Benedict RC, Smith JL, Swift CE (1977). Evaluation of rapid tests for monitoring alteration in meat quality during storage. $\mathrm{J}$ Food Prot 40: 843-847.

Tarakchi Z, Kucukoner E (2004) Physico-chemical, sensory and microbial quality of stirred yoghurt prepared with different fruit flavourings. J Food Sci Technol 41: 177-181.

Vahedi N, Tehrani MM, Shahidi F (2008) Optimizing of fruit yoghurt formulation and evaluating its quality during storage. AmericanEurasian J Agric Envir Sci 3:922-927.

Vasiljevic T, Kealy T, Mishra V K (2007) Effects of beta-glucan addition to a probiotic containing yoghurt. J Food Sci 72: 405-411 